\title{
Biological Control of Damping-Off of Tomato Seedlings and Cucumber Phomopsis Root Rot by Bacillus subtilis RB14-C
}

\author{
Nobuhiro KITA ${ }^{1 *}$, Takeshi OHYA ${ }^{2}$, Hidetoshi UEKUSA ${ }^{3}$, Ken NOMURA ${ }^{1}$, \\ Masahumi MANAGO ${ }^{4}$ and Makoto SHODA $^{5}$ \\ 1,2,4 Division of Biotechnology and Bio-Resources, Kanagawa Institute of Agricultural Science \\ (Hiratsuka, Kanagawa 259-1204, Japan) \\ ${ }^{3}$ Division of Agro-Environment, Kanagawa Institute of Agricultural Science \\ (Hiratsuka, Kanagawa 259-1204, Japan) \\ ${ }^{5}$ Chemical Resources Laboratory, Tokyo Institute of Technology \\ (Yokohama, Kanagawa 226-8503, Japan)
}

\begin{abstract}
Bacillus subtilis RB14-C, which is a streptomycin resistant mutant of B. subtilis RB14 isolated from compost, produces an antifungal peptide, iturin $\mathrm{A}$, and was evaluated for its suppressive ability against damping-off of tomato seedlings and Phomopsis root rot of cucumber. In damping-off disease of tomato seedlings caused by Rhizoctonia solani, RB14-C cell suspension treatment did not suppress the disease occurrence whereas germinated seed treatment of the RB14-C cells reduced the occurrence of the damping-off. In both treatments, iturin A could not be detected from the treated soil. In the Phomopsis root rot of cucumber, root immersion treatment of cucumber seedlings with RB14-C cell suspension at the time of transplanting effectively suppressed the root rot, resulting in growth recovery 50 days after the treatment even though the initial growth was retarded due to the Phomopsis infection. These results suggest that germinated seed treatment of RB14-C cells and root immersion treatment with RB14-C cell suspension can be applied as promising biological control practices of the dampingoff of tomato seedlings and the cucumber Phomopsis root rot, respectively.
\end{abstract}

Discipline: Plant protection

Additional key words: soil-borne disease, combined application, root immersion treatment

\section{Introduction}

Vegetable production in Japan depends on an intensive, labor-consuming production system, which frequently leads to deteriorating plant growth and yield loss resulting from successive cropping ${ }^{16}$. Among the various factors involved, soil-borne diseases comprise the major cause of the yield reduction ${ }^{2}$. Methyl bromide and chloropicrin (trichloronitromethane) have been generally used to control soil-borne diseases because of the stable effect and availability in the production system while biological and physical controls such as using microbial antagonists, resistant varieties and heat sterilization, are also applied as complementary means for plant protection $^{3,8,16}$. However, the use of methyl bromide will be banned in Japan as well as other industrial countries by the year of 2005 and worldwide by 2015 because methyl bromide has proven to deplete the ozone layer ${ }^{3,8}$. Although chloropicrin, dazomet, or metam sodium etc. are now used as short-term chemical alternatives to methyl bromide ${ }^{3}$, antagonistic microorganisms isolated from compost, which human beings have long been using as soil amendments, have become a topic of research as promising agents for biological control.

Various types of composts have been developed with the specific effects of antagonism, competition, parasitism, elicitation of plant defense responses, or plant growth promotion ${ }^{2,7,14,15}$. As for microbial antagonism, we have found that Bacillus subtilis, which was isolated

\footnotetext{
Present address:

${ }^{2}$ Agriculture Promotion Division, Kanagawa Prefectural Government (Yokohama, Kanagawa 231-8588, Japan)

${ }^{4}$ Tokyo University of Agriculture, Faculty of Agriculture (Atsugi, Kanagawa 243-0034, Japan)

*Corresponding author: fax +81-463-58-4254; e-mail kita.ihgr@pref.kanagawa.jp

Received 27 August 2004; accepted 8 December 2004.
} 
from compost, produces an antifungal peptide, iturin $\mathrm{A}^{1,9}$, and has a wide range of antifungal and antibacterial activities that can be used as a prominent biological control agent ${ }^{1,9,13}$. However, application conditions, spectrum of soil-borne diseases and persistency of the bacterium in the soil are major problems that still remain to be solved because the suppressive effect is not stable and does not persist long enough to sustain the expected yield.

In the present paper, we report the results of an evaluation of the suppressive ability of B. subtilis RB14-C, which is a streptomycin resistant spontaneous mutant of B. subtilis $\mathrm{RB} 14^{6}$, against damping-off of tomato seedlings and Phomopsis root rot of cucumber.

\section{Materials and methods}

\section{Biological control of damping-off of tomato seedlings}

(1) Plants

Tomato seeds of 'Ponderosa' were surface-sterilized by $70 \%$ ethanol followed by $0.5 \%$ sodium hypochlorite treatment for $10 \mathrm{~min}$, washed thoroughly by sterilized water for $5 \mathrm{~min}$, placed on a plate, and kept at $28^{\circ} \mathrm{C}$ in the dark. After $24 \mathrm{~h}$, one-third of the pre-germinated seeds were transferred to a new plate for the germinated seed treatments described below. The remaining seeds were further incubated for $48 \mathrm{~h}$. Thus, in both cases, 3 day-old, synchronously germinated seeds were used for the experiments.

(2) Preparation of infested soil

Rhizoctonia solani $\mathrm{K}-1$ isolated from cockscomb ${ }^{17}$ was grown on potato dextrose agar (PDA) plates at $28^{\circ} \mathrm{C}$ in the dark for 5 days. The mycelia were recovered from 5 plates with PDA medium, homogenized with $500 \mathrm{~mL}$ of sterilized water and then mixed with $1 \mathrm{~kg}$ of soilwheat bran medium (a mixture of clay soil and wheat bran at the ratio of $4: 1$ ) that had been autoclaved at $120^{\circ} \mathrm{C}$ with $1.2 \mathrm{~kg} / \mathrm{cm}^{2}$ pressure for $1 \mathrm{~h}$. After 20 -day incubation at $28^{\circ} \mathrm{C}$ in the dark, $1 \mathrm{~kg}$ of the soil-wheat bran inoculum was mixed with $5 \mathrm{~L}$ of clay soil pre-autoclaved twice at $120^{\circ} \mathrm{C}, 1.2 \mathrm{~kg} / \mathrm{cm}^{2}$ for $1 \mathrm{~h}$ every other day. The infested soil was then put in a plastic box (depth $\times$ width $\times$ length $=10 \times 5 \times 10 \mathrm{~cm}$ ) and used for the experiments. As for the control, the infested soil was re-autoclaved at $120^{\circ} \mathrm{C}$ and $1.2 \mathrm{~kg} / \mathrm{cm}^{2}$ pressure for $1 \mathrm{~h}$.

(3) Preparation of B. subtilis RB14-C and flutolanil

B. subtilis $\mathrm{RB} 14-\mathrm{C}$, which is a spontaneous streptomycin-resistant mutant of strain $\mathrm{RB} 14^{6}$ and a coproducer of the antifungal substances, iturin A and surfactin ${ }^{1,9}$, was grown in Luria-Bertani (LB) medium supplemented with $100 \mathrm{mg} / \mathrm{L}$ of streptomycin at $37^{\circ} \mathrm{C}$ for 4 days according to the method of Asaka and Shoda ${ }^{1}$. To exclude the antifun- gal substances secreted to the culture fluid, the cells were collected by centrifuging at $6,000 \times g$, washed and resuspended with sterilized water to give a concentration of ca. $10^{8} \mathrm{cfu} / \mathrm{mL}$ determined by measuring the optical density at $660 \mathrm{~nm}$. The actual number of cells in the applied cell suspension was determined by spreading the decimally diluted cell suspension on LB-agar plates (LB plus $1.5 \%$ agarose) supplemented with $100 \mathrm{mg} / \mathrm{L}$ of streptomycin at the time of application. Moncut ${ }^{\mathrm{R}}$ granules (Nihon Nohyaku Co., Ltd., Tokyo, Japan) containing 7\% of flutolanil were ground, sieved through $0.5 \mathrm{~mm}$ mesh and suspended with either sterilized water or the RB14-C cell suspension to give the final concentration of $500 \mathrm{mg} / \mathrm{L}$.

(4) RB14-C cell and flutolanil treatments

As for the pouring treatments, 20 germinated tomato seeds were sown at $1 \mathrm{~cm}$ depth and then $200 \mathrm{~mL}$ of RB14-C cell suspension, flutolanil suspension and the mixture of the two were gently applied by pouring onto the soil surface, respectively. In the germinated seed treatments, two sheets of filter paper were immersed in RB14-C cell suspension of $10^{8} \mathrm{cfu} / \mathrm{mL}$, put in a plate and then surface-sterilized tomato seeds that had been pregerminated at $28^{\circ} \mathrm{C}$ for $24 \mathrm{~h}$ in the dark were placed on the surface. After $48 \mathrm{~h}$ incubation at $28^{\circ} \mathrm{C}$ in the dark, 20 germinated seeds were then sown at $1 \mathrm{~cm}$ depth and then either $200 \mathrm{~mL}$ of sterilized water or flutolanil suspension was applied. Both pouring and germinated seed treatments were done on the same day in the same greenhouse. Sterilized water was used for the negative controls and each treatment was carried out in three replications with triplicates.

(5) Detection of iturin A from soil

As RB14-C has been shown to produce 5 homologous iturin $\mathrm{A}^{6}$ and can be detected in the soil that suppresses damping-off of tomato seedlings ${ }^{9}$, iturin A was extracted from the soil of each treatment according to the method of Asaka and Shoda ${ }^{1}$. The crude extracts from the soil were evaporated into dryness under reduced pressure, dissolved with $2 \mathrm{~mL}$ of methanol through $0.2 \mu \mathrm{m}$ mesh for high-performance liquid chromatography (HPLC) analysis. HPLC was preformed using SMART system (Amersham Pharmacia Biotech Inc., Tokyo, Japan) with sephasil C18SC2.1/10 column $(2.1 \mathrm{~mm}$ in diameter and $100 \mathrm{~mm}$ in length) and run with $10 \mathrm{~mol} / \mathrm{m}^{3}$ ammonium acetate and acetonitril as the developing solvent. The extracts were first absorbed to the resin after equibilizing with $10 \mathrm{~mol} / \mathrm{m}^{3}$ ammonium acetate for $5 \mathrm{~min}$ and then eluted with ammonium acetate by a gradient from 35 to $55 \%$ within $22 \mathrm{~min}$ at the elution speed of $200 \mu \mathrm{L}$ per min. The eluents were detected by absorbance at $205 \mathrm{~nm}$. For the HPLC standard, iturin A was purified from the culture fluid of RB14-C as described previously ${ }^{6}$. 


\section{Biological control of Phomopsis root rot of cucumber by RB14-C}

(1) Plants

Cucumber seeds of 'Sagami-Hanjiro' were sown in pots and grown in a greenhouse at $25 / 15^{\circ} \mathrm{C}$ (day/night) for 10 days. Hyponex liquid fertilizer (6-10-5 for all purpose; HYPONEX JAPAN Corp., Ltd., Osaka, Japan) was applied at a 2,000-fold dilution every other day. When the first true leaves were fully developed, 10 seedlings were taken for each treatment and the roots were soaked in tap water to gently remove the attached soil.

(2) Preparation of infested soil

Phomopsis sp. M-1 isolated from infected summer squash (Cucurbita maxima) (Uekusa 1992, unpublished) was grown on PDA plates at $25^{\circ} \mathrm{C}$ for 14 days in the dark. The mycelia were recovered from 5 plates with PDA medium, homogenized with $500 \mathrm{~mL}$ of sterilized water and then mixed with $5 \mathrm{~L}$ of sterilized clay soil and incubated at $25^{\circ} \mathrm{C}$ for $24 \mathrm{~h}$ in the dark before use. As for the control, the infested soil was autoclaved at $1.2 \mathrm{~kg} / \mathrm{cm}^{2}$, $120^{\circ} \mathrm{C}$ for $1 \mathrm{~h}$.

(3) Root immersion treatment

B. subtilis RB14-C cell suspension of $10^{8} \mathrm{cfu} / \mathrm{mL}$ was prepared as mentioned above. Roots of the cucumber seedlings were immersed in the cell suspension, kept for $30 \mathrm{~min}$ and planted in pots with $500 \mathrm{~mL}$ of infested or sterilized soil. Sterilized water was used as the control. After giving $200 \mathrm{~mL}$ of sterilized water per each pot, the seedlings were grown in a greenhouse at $25 / 15^{\circ} \mathrm{C}$ (day/ night). Hyponex liquid fertilizer (6-10-5 for all purpose) was applied at a 2,000-fold dilution every other day. Three replications with triplicates using 10 seedlings per each treatment were performed.

\section{Results}

\section{Effects of RB14-C and flutolanil on the occurrence of damping-off of tomato seedlings}

Effects of pouring and germinated seed treatments of RB14-C cell suspension, flutolanil and the mixture of the two on the occurrence of damping-off of tomato seedlings were determined 14 days after treatment and the results are summarized in Table 1. In the pouring treatment of RB14-C cell suspension, there was no significant difference in the occurrence of the damping-off with that of the positive control (Fig. 1-2,3), indicating that the single RB14-C cell suspension treatment has no suppressive effect on the disease occurrence. In contrast, flutolanil

Table 1. Effect of Bacillus subtilis RB14-C and flutolanil on the occurrence of damping-off of tomato seedlings caused by Rhizoctonia solani

\begin{tabular}{lr}
\hline \hline Treatments & Damping-off (\%) \\
\hline Pouring treatment & \\
Disinfested soil + water & $0.6^{\mathrm{c}} \pm 1.0$ \\
Infested soil + water & $23.9^{\mathrm{a}} \pm 31.3$ \\
Infested soil + RB14-C & $29.4^{\mathrm{a}} \pm 34.3$ \\
Infested soil + flutolanil & $10.5^{\mathrm{b}} \pm 7.5$ \\
Infested soil + RB14-C + flutolanil & $6.5^{\mathrm{c}} \pm 3.1$ \\
& \\
Germinated seed treatment & $4.2^{\mathrm{c}} \pm 3.5$ \\
Disinfested soil + water & $15.8^{\mathrm{b}} \pm 4.4$ \\
Infested soil + RB14-C & $5.0^{\mathrm{c}} \pm 2.4$ \\
Infested soil + RB14-C + flutolanil & \\
\hline Data represent the average and standard deviation. The same \\
letters within a column are not significantly (P<0.05) differ- \\
ent from each other according to Fisher's protected LSD test.
\end{tabular}

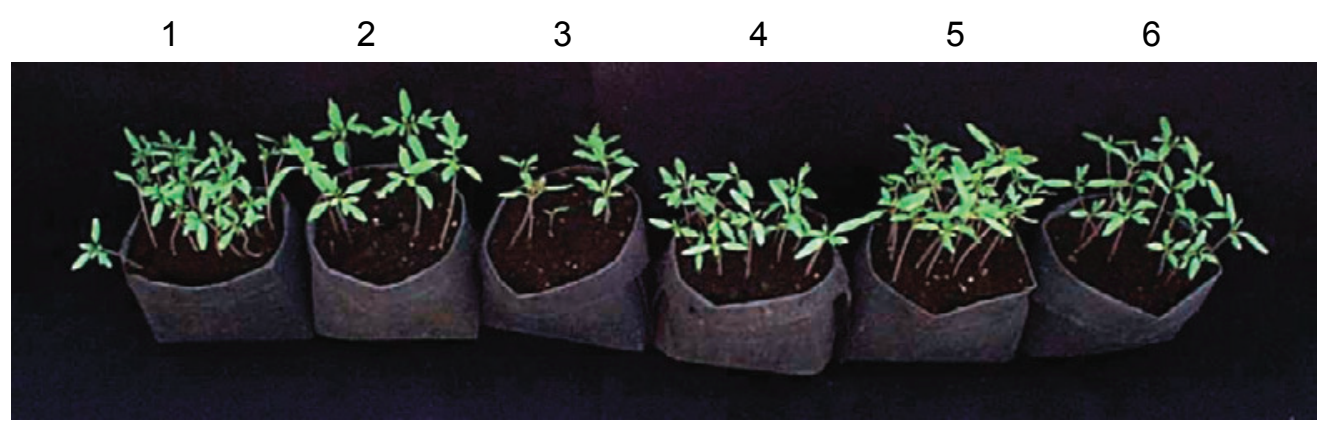

Fig. 1. Effects of Bacillus subtilis RB14-C and flutolanil on the occurrence of damping-off of tomato seedlings caused by Rhizoctonia solani

Tomato seeds were pre-germinated at $28^{\circ} \mathrm{C}$ in the dark for $72 \mathrm{~h}$ and sown in (1): Clay soil disinfested by autoclave, (2-6): Clay soil infested with Rhizoctonia solani; followed by application of (1,2): Water, (3): RB14-C, (4): Flutolanil, (5): Combination of RB14-C and flutolanil. (6): The result of germinated seed treated by RB14-C cell suspension $\left(10^{8} \mathrm{cfu} / \mathrm{mL}\right)$ at the time of pre-germination for $48 \mathrm{~h}$ in the same condition. 
treatment effectively suppressed the damping-off (Fig. 14), confirming the anti-rhizoctonial activity. In case of the combination treatment of RB14-C and flutolanil, the level of the suppressiveness was enhanced compared with the single flutolanil treatment, resulting in the lower disease occurrence (Fig. 1-5). When the germinated seeds were treated with RB14-C cell suspension before seeding, aiming to let RB14-C cells colonize the tomato rhizosphere, the occurrence of damping-off was significantly lower than that of the positive control in the pouring treatments (Fig. 1-6). No significant difference was observed in the disease occurrence between the negative controls of pouring and germinated seed treatments, indicating that RB14-C cells did not affect the vigor of the germinating tomato seeds. Interestingly, RB14-C application in both pouring and germinated seed treatments enhanced the level of the suppressiveness of the flutolanil application.

\section{Detection of iturin A from soil}

HPLC analysis in the present study could detect 5 peaks comprising iturin $\mathrm{A}$ at the lowest concentration of $2 \mathrm{mg} / \mathrm{mL}$ using the standard compound (Fig. 2A). When tomato rhizosphere soil samples were taken 8 days after pouring and germinated seed treatments, no noticeable peaks of iturin A were detected in any of the soil extracts including the soil treated with RB14-C cell suspension (Fig. 2B). In contrast, the positive control soil, in which $3 \mathrm{~mL}$ of $10 \mathrm{mg} / \mathrm{mL}$ iturin A was pre-mixed with the infested soil just before sampling, showed 5 typical peaks corresponding to the 5 homologous iturin A (Fig. 2C). In this case, the recovery rate was approximately $80 \%$.

\section{Suppression of Phomopsis root rot of cucumber}

The effect of RB14-C on the suppressiveness of Phomopsis root rot of cucumber was determined. When cucumber seedlings were taken, their roots washed gently, and immersed in the RB14-C cell suspension before planting in the infested soil, the growth of the seedlings was retarded at first for several weeks probably due to the Phomopsis infection. Accordingly, as shown in Fig. 3A on 50 days after treatment, RB14-C-treated seedlings were apparently small in size compared with the negative control but all the plants recovered and started to grow vigorously thereafter. In contrast, the growth of the positive control plants was severely affected. Plant shoot weight, root weight, and leaf number 50 days after treatment reflected the difference as shown in Fig. 4. The shoot weight and leaf number clearly represented a difference among the treatments, indicating that the root damage induced by Phomopsis infection greatly affected the plant growth. Roots of the RB14-C treated seedlings, however, showed almost the same mass as that of the disinfested, negative control soil in spite of the growth retardation. Root browning was also significantly reduced whereas the roots of the positive control turned brown and severely rotted (Fig. 3B). The difference in the average root weight apparently reflected the growth difference among the treatments but there was statistically no significant difference between RB14-C treatment and the negative control (Fig. 4-B).

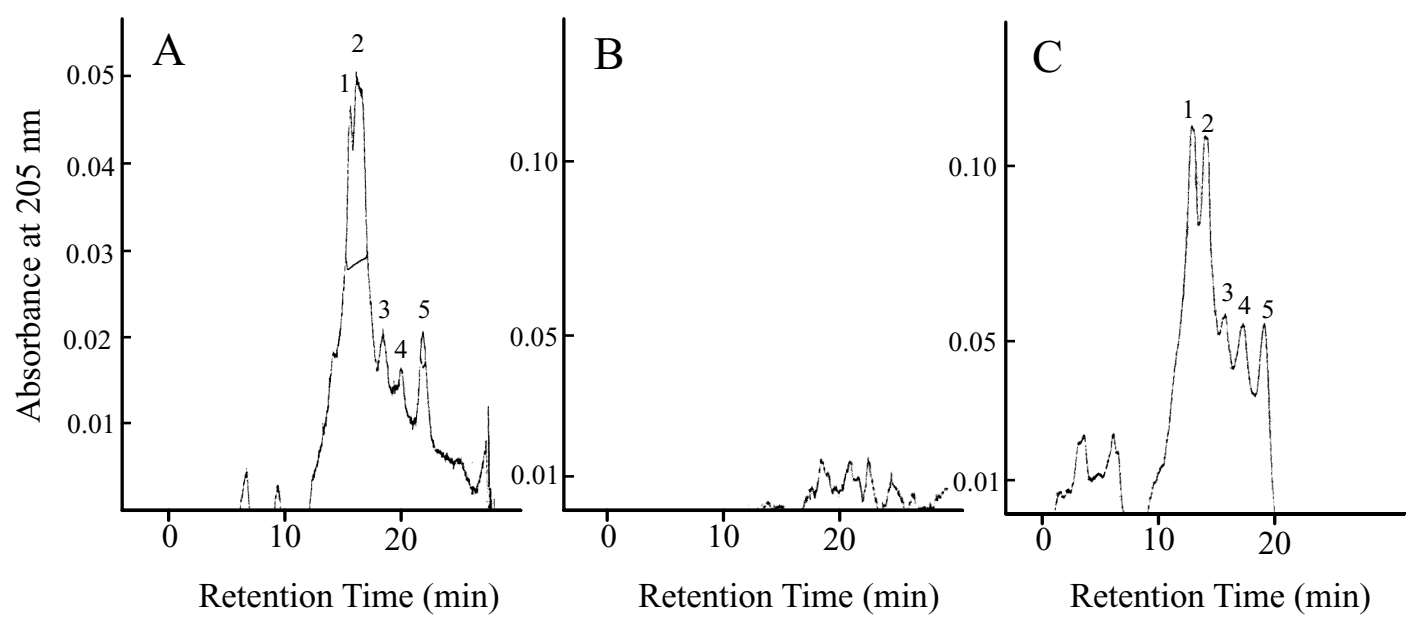

Fig. 2. Detection of iturin A by HPLC

A: Standard chromatogram of 2 ppm iturin A purified from culture fluid of Bacillus subtilis RB14-C.

B: Chromatogram of extract from clay soil infested with Rhizoctonia solani, in which tomato seedlings have been grown for 30 days after pouring B. subtilis RB14-C cell suspension $\left(10^{8} \mathrm{cfu} / \mathrm{mL}\right)$.

$\mathrm{C}$ : Chromatogram of clay soil extract from $10 \mathrm{~g}$ of the same infested clay soil just after pouring $3 \mathrm{~mL}$ of 10 ppm iturin A standard solution. 1-5: Five homologous iturin A. 

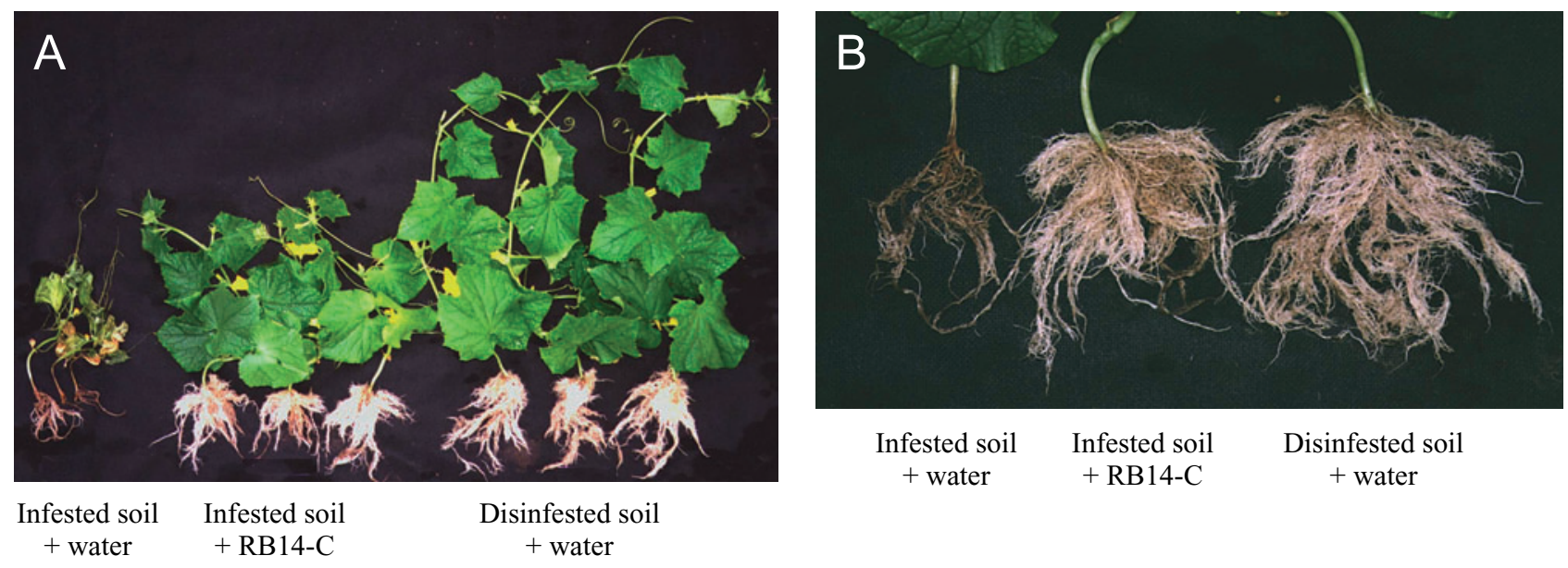

Fig. 3. Suppression of cucumber root rot caused by Phomopsis sp. 50 days after root immersion treatment of Bacillus subtilis $\mathrm{RB} 14-\mathrm{C}$ cell suspension $\left(10^{8} \mathrm{cfu} / \mathrm{mL}\right)$

A: Growth of cucumber treated with water in the infested soil, RB14-C in the infested soil and water in disinfested soil from the left, respectively.

B: Roots of cucumber treated with water in the infested soil, RB14-C in the infested soil and water in disinfested soil from the left, respectively.
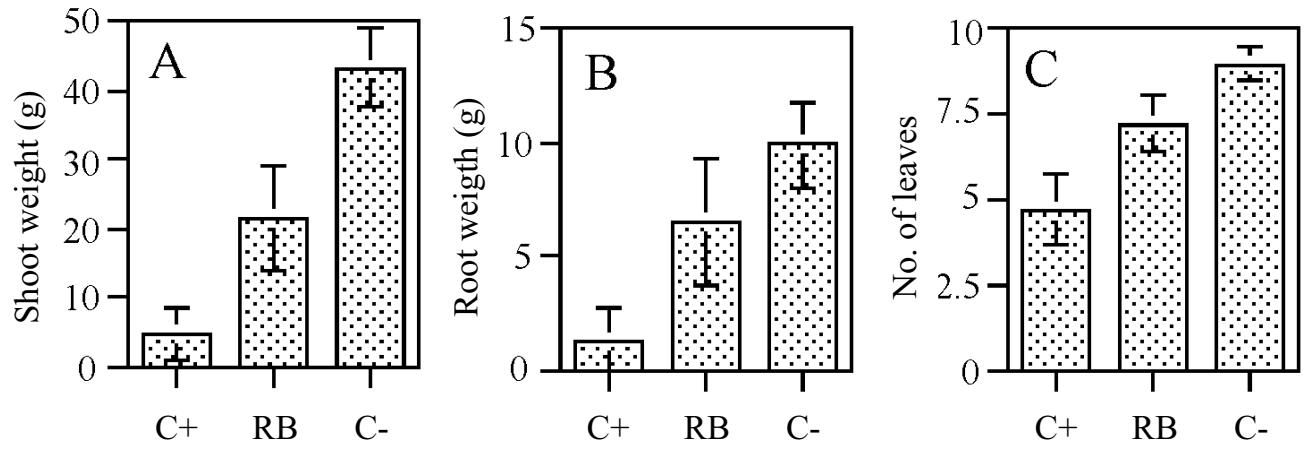

Fig. 4. Suppression of cucumber root rot caused by Phomopsis sp. 50 days after root immersion treatment of Bacillus subtilis $\mathrm{RB} 14-\mathrm{C}$ cell suspension $\left(10^{8} \mathrm{cfu} / \mathrm{mL}\right)$

A: Shoot weight, B: Root weight, C: Leaf number.

$\mathrm{C}+$ : Plants grown in the infested soil after the roots were treated with water.

RB: RB14-C cell suspension. C-: Disinfested soil treated with water.

Data represent the average and standard deviation (bars) obtained from the results of 3 replications with triplicates using 10 plants per each treatment.

\section{Discussion}

In the damping-off diseases caused by $R$. solani, Asaka and Shoda ${ }^{1}$ have shown by using antagonistic $B$. subtilis that effective suppression could be achieved only when the bacterial culture filtrates containing iturin A were present and thus the disease suppression depends on the antibiotic activity of iturin A. They also found that most of the viable cells of $B$. subtilis in the soil are in the form of spores that have no ability to produce antibiotics $^{1}$. In the present study of the pouring treatment of the RB14-C cell suspension, in which culture fluid containing iturin A was removed, iturin A could not be detected from the treated soil and, accordingly, the occurrence of damping-off of tomato seedlings caused by $R$. solani could not be suppressed even though high-densities of RB14-C cells were applied. On the contrary, seed treatment of RB14-C cells at the time of germination reduced the disease occurrence as reported by other studies $^{10,11}$. In addition, the anti-rhizoctonial effect of flutolanil was enhanced by the simultaneous application of the RB14-C cell suspension and the use of germinated seeds pre-treated with RB14-C cells. Although the detailed mechanisms of the enhanced suppressiveness are 
unclear, these results suggest that the germinated seed treatment of RB14-C can be used as a simple biological control practice especially when used in combination with flutolanil application ${ }^{5}$.

Phomopsis sp., causal agents of root rot disease of cucurbitaceae, grow slowly and are known to have relatively weak pathogenicity ${ }^{4}$. Actually, it takes a longer duration until they successfully colonize cucumber roots and induce root rot symptoms than other soil-borne disease pathogens such as $R$. solani used in the present study. This time lag for the expression of pathogenicity, in turn, is considered to be beneficial to antagonistic microorganisms in terms of their successful colonization in the rhizosphere and/or root surface. Moody and Gindrat ${ }^{12}$ isolated Gliocladium roseum that paratisizes a cucumber pathogen, Phomopsis sclerotioides, and showed that G. roseum could effectively suppress the occurrence of the disease. In the present study, roots of cucumber seedlings were immersed in RB14-C cell suspension at the time of transplanting to let the bacterium colonize the cucumber roots. As expected, the root rot was suppressed resulting in growth recovery 50 days after treatment even though initial growth was retarded probably due to the Phomopsis infection. Further experiments will be carried out to establish a systematic disease control practice that can be employed in commercial production using antagonistic $B$. subtilis.

In summary, we have shown that germinated tomato seed treatment of RB14-C cells and root immersion treatment using RB14-C cell suspension in cucumber seedlings at the time of transplanting reduced the occurrence of the damping-off of tomato seedlings and Phomopsis root rot of cucumber, respectively. These results suggest that germinated seed treatment of RB14-C cells and root immersion treatment with RB14-C cell suspension can be applied as promising biological control practices of the damping-off of tomato seedlings and the cucumber Phomopsis root rot, respectively. Further experiments for the practical use of antagonistic rhizosphere-colonizing microorganisms will be required.

\section{Acknowledgements}

This paper reports the results supported by Grant-inAid for Scientific Research (B), The Ministry of Education, Science, Sports and Culture.

\section{References}

1. Asaka, O. \& Shoda, M. (1996) Biocontrol of Rhizoctonia solani damping-off of tomato with Bacillus subtilis
RB14. Appl. Environ. Microbiol., 62, 4081-4085.

2. Cook, R. J. (2000) Advances in plant health management in the twentieth century. Annu. Rev. Phytopathol., 38, 95-116.

3. Duniway, J. M. (2002) Status of chemical alternatives to methyl bromide for pre-plant fumigation of soil. Phytopathology, 92, 1337-1343.

4. Ebben, M. H. \& Last, F. T. (1967) A sclerotial fungus pathogenic to cucumber roots. Plant Pathol., 16, 96.

5. Guetsky, R. et al. (2001) Combining biocontrol agents to reduce the variability of biological control. Phytopathology, 91, 621-627.

6. Hiraoka, H. et al. (1992) Characteristics of Bacillus subtilis RB14-coproducer of peptide antibiotics iturin A and surfactin. J. Gen. Appl. Microbiol., 38, 635-640.

7. Hoitink, H. A. J. \& Boehm, M. J. (1999) Biocontrol within the context of soil microbial communities: A substrate-dependent phenomenon. Annu. Rev. Phytopath., 37, 427-446.

8. Kita, N., Nishi, K. \& Uematsu, S. (2003) Hot water treatment as a promising alternative to methyl bromide. In Proceedings of 2003 annual international research conference on methyl bromide alternatives and emissions reductions, ed. Obenauf, G. E., Methyl Bromide Alternatives Outreach, Fresno, CA. 26·1-26·4.

9. Kondoh, M., Hirai, M. \& Shoda, M. (2001) Integrated biological and chemical control of damping-off caused by Rhizoctonia solani using Bacillus subtilis RB14-C and flutolanil. J. Biosci. Bioeng., 91, 173-177.

10. Merriman, P. R., Price, R. D. \& Baker, K. F. (1974a) The effect of inoculation of seed with antagonists of Rhizoctonia solani on the growth of wheat. Aust. J. Agri. Res., 25, 213-218.

11. Merriman, P. R. et al. (1974b) Effect of seed inoculation with Bacillus subtilis and Streptomyces griseus on the growth of cereals and carrots. Aust. J. Agri. Res., 25, 219-226.

12. Moody, A. R. \& Gindrat, D. (1977) Biological control of cucumber black root rot by Gliocladium roseum. Phytopathology, 67, 1159-1162.

13. Phae, C. G. et al. (1992) Biological control of crown and root rot and bacterial wilt of tomato by Bacillus subtilis NB22. Ann. Phytopath. Soc. Jpn., 58, 329-339.

14. Raupach, G. S. \& Kloepper, J. W. (1998) Mixtures of plant growth-promoting rhizobacteria enhance biological control of multiple cucumber pathogens. Phytopathology, 88, 1158-1164.

15. Tuitert, G., Szczech, M. \& Bollen, G. J. (1998) Suppression of Rhizoctonia solani in potting mixtures amended with compost made from organic household waste. Phytopathology, 88, 764-773.

16. Uematsu, S., Nishi, K. \& Kita, N. (2003) Hot water soil sterilization begins in Japan. Farming Jpn., 37, 35-41.

17. Ushiyama, K. et al. (1987) Damping-off of feather cockscomb (Celosia argentea L. var. cristata O. Kuntze) caused by Rhizoctonia solani Kühn. Kanagawa-ken engeishikenjo kenkyu-houkoku (Bull. Kanagawa Hort. Exp. Stn.), 34, 33-37 [In Japanese with English summary]. 